\title{
TRAINING AND FOSTERING THE CONTINGENT OF POLICE CADRES OF HAI PHONG CITY TO MEET THE REQUIREMENTS AND MISSIONS OF ENSURING SECURITY AND ORDER IN THE NEW SITUATION
}

\section{Tinh Dang Nguyen}

\section{Article History}

Received: 11 October 2020

Accepted: 20 November 2020

Published: 30 December 2020

\section{Keywords}

Training, fostering, policemen, Hai Phong city

\author{
Hai Phong Police Department, Vietnam \\ Email:nguyendang2812@gmail.com
}

\section{INTRODUCTION}

The Government's Decree on training and fostering cadres, civil servants and public employees (Government, 2017) emphasizes: "The goal of training and fostering is to equip knowledge, skills and task implementation methodologies in public service activities of cadres, civil servants and public employees' professional activities, contributing to developing a contingent of professional cadres, civil servants and public employees with good ethical qualities, strong political standpoint, and professional capabilities to meet the requirements of serving the people and the development of the country". Accordingly, there should be sufficient research and timely adjustment of training, fostering and improving professional qualifications for the contingent of police officers to meet the new requirements on the employment of public security officers in the new situation.

The article proposes a number of basic solutions to improve the quality of training and fostering for the staff of Hai Phong Police to meet the requirements and missions of ensuring security and order in the new situation.

\section{LITERATURE REVIEW}

According to Olaniyan and Ojo (2008), employee training and development is based on the foundation that employee skills need to be improved to organize and develop. The newcomers to the organization have many different skills although not all of them suit the organization's needs. Training and development is necessary for employees to work towards bringing the organization to the desired targets.

When discussing the role of training and fostering cadres and civil servants in public service activities, Trinh Viet Tien (2018) focused on clarifying the role and orienting solutions for training and fostering activities to maintain cadres and civil servants for public service implementation with the highest efficiency and contribution to the country development.

According to Tong Quoc Binh (2016), improving the quality of training and fostering for officials in the current people's public security force must emphasize on perfecting the system of staff training and fostering institutions; ensuring the uniformity of criteria, standards and structure for all professions, at the same time increasing funding for training and fostering to develop a strong people's police force.

Dang Viet Xo (2016) posed a number of issues about the current situation of education and training in the People's Public Security forces such as how the system of training institutions of the People's Public Security have continued to develop and gradually asserted its position in the national education system; the contents, programs, training methods, teaching materials curriculum in the People's Public Security Forces have been gradually completed and standardized; the contingent of lecturers has gradually improved their qualifications; institutions have gradually built up output standards,... 
Discussing building the contingent of grassroots cadres and civil servants of Hai Phong city, Nguyen Tho Anh (2019) proposed that there must be a plan to train and foster grassroots cadres that strictly complies with the regulations on recruitment, usage, arrangement and transferring of cadres and civil servants.

It can be seen that while a number of literature has been raised for the training and fostering of police officers; due to the new requirements of the force, it is necessary to continue researching on this issue for the police force of each specific unit.

\section{RESEARCH METHODS AND RESULTS}

\subsection{Research methods}

The article is based on analytical research methods, synthesizing theoretical and practical resources related to the training and fostering of the police force; documents, resolutions, circulars, decisions of the Party, State, Ministry of Public Security; research projects related to the study such as scientific articles, scientific reports, and monographs. Along with that, the article also uses document research methods to summarize experience in building and developing the contingent of police officers.

The subject of the study is the contingent of police officers currently performing the task of ensuring security and order in Hai Phong city.

\subsection{Research results}

\subsubsection{The current situation of training and fostering the police cadres of Hai Phong city}

As determining the meaning and importance of professional training and fostering for police cadres is one of the important tasks in public security force development, over the past years, the Party Committee and leadership of Hai Phong city People's Public Security have actively concretized and implemented the resolutions, regulations and instructions of the Party Committee of the Central Public Security and the Ministry of Public Security on cadre officers work, training and fostering; provided attention and investment in training and fostering the staff; coordinated with academies, institutions in the People's Public Security sector as well as relevant units to organize training classes according to the State's regulations and the Ministry of Public Security. Thereby, the work of management, training, fostering, planning and arranging staff with job titles and working professional capabilities has achieved positive results. Most of the city's police staff are formally trained in accordance with the force's regulations. In general, the trained and fostered staff are equipped with relatively comprehensive social knowledge; a scientific mindset; strong political standpoint; sufficient amount of professional qualifications and knowledge in law and politics; and capabilities of responding to the practical situation of security and order protection in many fields and areas. Most of the staff have carried out their assigned functions and duties, making the best use of their roles, strengths and working capacity (Truong Giang Long, 2015).

However, in the current context of international integration and new requirements arising in the mission of ensuring security and order, the contingent of police officers in Hai Phong city still has certain limitations; one of the most prominent reasons of which is that the training and fostering reformation of cadres are still relatively slow, not closely reaching the combination of theory with practice, and not associated with planning and by ranking titles. In some districts, after being fostered, police officers at ward and commune levels are not arranged in the right areas with their trained and fostered expertise. The investment of funds for training, fostering resources and facilities has not met the requirements of the task of ensuring security and order, therefore, has somewhat affected the working quality of the staff.

3.2.2. The current situation of social security and order in regards with police cadre training and fostering activities

In the coming time, in the world, peace and cooperation for development will still be the key trend. However, the security and order situation have continued to develop with complications. Therefore, the task of fighting against and combating anti-sabotage activities by hostile and reactionary forces and crimes to contribute to maintaining sociopolitical stability, protecting national security, preserving social order and safety is regarded as the top priority, requires the People's Public Security force to continue striving to deserve a core role in the mission of national security protection, order maintenance and social safety, excellently completing the assigned targets.

Hai Phong is the largest port city in the North and is a gateway for international exchange in terms of land, sea and air. Together with other provinces in the country, in recent years, Hai Phong Party Committee, government and people have made great efforts in developing socio-economic development, maintaining security and order. However, compared to some other provinces, Hai Phong has its own specific characteristics. Being a locality with 
highly active economic development in all sectors of economy and services, especially economic in sea transport, Hai Phong's population is extremely diverse. Currently, the criminal activities are highly complicated, making the situation of security and order sometimes not really stable. In particular, in recent time, the crime situation has many complicated development, along with the trend of internationalization, there are a number of new criminal groups and types affecting the security and order situation as well as the peaceful, healthy and happy life of people in Hai Phong city. In order to meet the new requirements of ensuring security and order, it is necessary to train and foster a contingent of qualified Hai Phong police officers who are ethical, qualified and capable, with a high spirit of selflessness, patriotism, dedication to serve the people, resourcefulness and bravery.

3.2.3. Solutions to improve the efficiency of training and fostering police cadres in Hai Phong city to satisfy new requirements of security and order in the new situation

\subsubsection{Clarifying the training and fostering targets and requirements for police cadre contingent}

According to the Central Executive Committee's requirements to the public security force (2018): "bearing absolute loyalty to the Party, the Motherland and the People, ready to fight and sacrifice for the independence and freedom of the Motherland, for the happiness of the people; having a sense of strict discipline with high fighting strength; possessing a reasonable quantity and structure, meeting the requirements of building a revolutionary, regular, elite force that reaches step by step modernization; with $20-30 \%$ able to work in an international environment". Thus, the objectives of training and fostering the police force of Hai Phong city must ensure that the cadres are qualified and capable, with a strong political standpoint and solid knowledge in law, science and technology, foreign languages and skills to perform the function of state management of security, order, protection of national security, maintaining security, social order and safety, keeping pace with the socio-economic development of the country and step by step meeting the general trend of the region and the world. Continuing to improve the system of training establishments, fostering training; determine the scale of occupations, training levels in accordance with the structure, the national education system and the planning for human resource development of the force. Education and training development must be associated with the requirements of ensuring security and order and building Hai Phong City People's Public Security force.

In order to avoid wastefulness in training, it is necessary to conduct a comprehensive annual survey of training qualifications and demands which closely follows the training and fostering targets of the Ministry of Public Security and the directions of the Hai Phong City police force. This acts as an analysis and evaluation to determine the difference between the existing competencies in performing actual tasks (including: qualifications, skills, qualities, attitudes) and the level of qualifications required for each job position. The issues posed for the training and fostering course is to "fill" the "gap", "solve" the "difference". The exact determination of training requirements is the basis for planning, compiling programs, organizing training and evaluating results, learning from experience for the future cohorts.

\subsubsection{Reforming the training content, program, curriculum and teaching methodologies}

The content of training and fostering programs needs to define a system of education levels and training levels appropriate for the functions, tasks, organizational structure and direction of force allocation at each level in the Public Security sector. It is also necessary to clearly define and classify knowledge at each level to ensure stability, linkage between educational levels, learning systems and the compulsory amount of knowledge, requirements on qualifications and skills of staff upon graduating; identifying a list of training sectors in the direction of research and development to train advisory and strategy research staff; researching and implementing a number of new scientific subjects in forecasting, strategic consulting, leadership science, commanding, non-traditional security, information security, cybercrime and new crime.

Other contents include: Actively innovating more modern teaching methods; promoting thorough integration between theory and practice; enhancing the interaction between teachers and students through practical situations to practice skills for students. Focusing on generalization and professional development; synthesizing and updating experience in the field of work undertaken; the ability to analyze and apply theories, knowledge, experiences and initiatives to practical task performance; the ability to build relationships, resolve conflicts, and control emotions; fostering professional ethics; analysis, coordination, information communication and multi-tiered transmission, understanding of targeted objects to ensure security and order; and the professional skills of the force. Along with that, it is necessary to strengthen cooperation with professional police units of the provinces and cities in teaching, 
practising, training, interning and solving professional situations in training and fostering the police cadre contingent in order to adapt to the tasks set out by the practical situation of ensuring social security, order and safety in Hai Phong city.

\subsubsection{Improving the quality of police cadres contingent lecturers and trainers}

The teaching staff play an important role in deciding the quality of the course because it is the team that directly transmits knowledge and skills to the trained and fostered subjects. Therefore, improving the quality of the contingent of teachers is a breakthrough, a focus in the fundamental and comprehensive innovation of education and training. Currently, the contingent of teachers of the people's police force is increasing in number, qualifications, capacities, pedagogical methods and scientific research capabilities.

However, in order to meet the requirements of training and fostering the current contingent of police officers in Hai Phong city, the faculty still needs to strive, continue to learn to improve their qualifications, cultivate knowledge, pedagogical skills and practical experience related to the teaching content. Above all, in any circumstances, the teaching staff must always possess a strong ideological and political viewpoint, acting as a shining example of morality, lifestyle, personality, and absolute loyalty to the Party, State and People. On the other hand, it is necessary to absolutely remove from the contingent of lecturers ones who are insufficiently qualified, professional, standardized, and exemplary. By doing this, the contingent of teachers of the people's public security force will be clean and strong with a deeper sense of responsibility as both a teacher and a people's police officer in order to constantly improve their education, knowledge, expertise and experience (Nguyen Hong Quang, 2009).

\subsubsection{Integration of training and fostering to arrangement and usage of the police cadre contingent}

The practice has proven that if agencies and units do not possess qualified staff with compulsory training and operate based on experiences only, the quality and efficiency of work will not be high due to the lack of breakthrough and creativity (Nguyen Yen Thanh, 2018). Therefore, the training and fostering of police officers must ensure that they meet the standards of professional titles and job positions. In parallel with the training and fostering at the training institutions of the Party Committee of Hai Phong city police, it is necessary to efficiently rotate cadres and sending them to practise in accordance with the national and local regulations at the grassroot level to accumulate experience and foster practical capacity for staff.

In addition, it is necessary to research, implement appropriate management methods and make use of the city police staff to create a favorable environment to help them practise, contribute and grow. In particular, it is necessary to pay attention to training young cadres and adopt policies to preserve and attract high-quality human resources. At the same time, it is essential to regularly select and send the city police staff to study abroad or receive in-depth training after graduating to have a contingent of talented successive intellectuals in each field, contributing to develop a clean and strong people's police force, worthy of being the core of the people's public security forces in the cause of protecting national security and maintaining social order and safety.

\section{DISCUSSION AND CONCLUSION}

Improving the working quality of the contingent of police officers in Hai Phong city is a purposeful, organized activity of responsible organizations and forces in the development of training programs, plans and contents. Training and fostering the contingent of police officers in terms of the meaning of an activity in the organization are the process of changing the contingent of cadres to achieve the knowledge, skills and capacity to perform their public service duties effectively; actively contribute to building a revolutionary, regular, elite and comprehensively strong People's police force, meeting requirements and missions in the new situation. Therefore, it is necessary to pay attention and invest in the training and fostering of police officers as both the driving force and the goal of the comprehensive revolution and national reform. In other words, investment in the development of the public security force is the investment in sustainable development that results in urgent, strategic and long-term effects.

\section{REFERENCES}

Central Executive Committee (2018). Resolution No. 26-NQ/TW dated May 19, 2018 The Seventh Conference of Session XII on building the contingent of cadres at all levels, especially at strategic levels, with sufficient qualities, capabilities and prestige satisfying the current range of missions.

Government (2017). Decree No. 101/2017/ND-CP dated September 1, 2017 of the Government on training and fostering of cadres, civil servants and public employees. 
Dang Viet Xo (2016). The current situation and solutions to improve the quality of education and training among the People's Public Security force. Journal of Education, special issue of July 1, 79-81; 78.

Nguyen Hong Quang (2009). Developing the People's Public Security Forces to meet the requirements of international economic integration. State Management Journal, 167, 27-31.

Nguyen Tho Anh (2019). Developing a contingent of grassroots cadres and civil servants of Hai Phong city. Journal of Political Theory, 7, 95-99.

Nguyen Yen Thanh (2018). Building a clean and strong People's Public Security force in the spirit of the Resolution of the 4th Central Conference Session XII. Journal of Communism (institutional subject), 140, 62-66.

Olaniyan, D. A., \& Ojo, L. B. (2008). Staff training and development: A vital tool for organizational effectiveness. European Journal of Scientific Research, 24(3), 326-331.

Tong Quoc Binh (2016). Improving the quality of training and fostering for officials in the People's Public Security force. Journal of Educational Management, 6, 11-14.

Trinh Viet Tien (2018). The role of the training and fostering of cadres and civil servants in public service performance. Journal of Industry and Trade, 5+6, 186-190.

Truong Giang Long (2015). Absolute devotion to the Country, absolute service to the People - The driving force of victories for the Vietnam People's Public Security. Journal of Theoretical Education, 234, 16-19. 